\title{
CHRONOLOGY OF CARLYLE'S LIFE
}

1795 Thomas Carlyle born on December 4 in Ecclefechan, Scotland.

1801 Jane Baillie Welsh born in Haddington, near Edinburgh, on July 14 .

1806 Carlyle enrolls as a day student at Annan Academy.

1809 Begins his education at the University of Edinburgh.

1813 Enrolls in Divinity Hall to fulfill his parents' expectation that he will become a minister.

1814 Leaves the university and returns to Annan Academy as mathematics tutor.

1816 Meets Edward Irving, a teacher and minister. Begins teaching in parish school in Kirkcaldy near Edinburgh.

1817 Tours the Highlands and western Scotland with Irving. Writes articles, letters to newspapers, and occasional poems on scientific and philosophic subjects.

1819 Moves to Edinburgh.

1820 Does translations from the French; writes a series of encyclopedia articles.

1821 Irving introduces him to Jane Welsh. Carlyle takes a wellpaid position, arranged by Irving, as a private tutor to Charles and Arthur Buller.

1822 Has a conversion experience in Leith Walk, near Edinburgh, in which he commits himself to the primacy and importance of work, rather than belief or theology, as the essence of personal self-definition. With his brother John's help, he translates Legendre's Elements of Geometry.

1823 Translates Goethe's Wilhelm Meister (1824) and expands an article on Schiller into The Life of Schiller (1825).

1824 Beginning in June, makes an extended visit to London. A guest of the Buller family and the Irving circle, he is introduced to London literary society, including Coleridge and Charles Lamb. 
1825 Translates various German authors, and falls strongly under the influence of Goethe.

1826 Marries Jane Baillie Welsh on October 17. Begins an autobiographical bildungsroman, the unfinished Wotton Reinfred.

1827 Francis Jeffrey, editor of the Edinburgh Review, becomes his patron and family friend. Jeffrey publishes a series of Carlyle's review-essays, mainly on German literature and culture, which initiate his Scottish and English reputation. German $R_{0}$ mance published in four volumes.

1828 Unsuccessful efforts to find suitable employment. Carlyles move to Craigenputtoch, a remote farm near Dunscore.

1828-29 Publishes "Burns" and "Signs of the Times" in the Edinburgh Review and articles on German literature in the Foreign Review.

1830 "On History" published in Fraser's Magazine. Begins Sartor Resartus.

1831 In London for an extended visit, he renews contact with the Buller-Irving circle, begins a friendship with John Stuart Mill, and unsuccessfully tries to find a publisher for Sartor Resartus. "Characteristics" published in the Edinburgh Review.

1832 Death of his father, James Carlyle. Thomas writes a substantial memoir of him, later included in Reminiscences (1881). Carlyles return to Craigenputtoch.

1833 Sartor Resartus is published serially in Fraser's Magazine from November 1833 to August 1834 . Encouraged by Mill, he begins to write about the French Revolution ("The Diamond Necklace"). In August, Emerson visits Carlyle at Craigenputtoch, the beginning of a lifelong friendship. Carlyle gives thought to emigrating to America.

1834 The Carlyles move to 24 Cheyne Row, London, their residence for the remainder of their lives. Edward Irving dies. In September, Carlyle begins to write The French Revolution.

1835 In March he is forced to begin The French Revolution again when the only copy of the manuscript (one-third completed) is accidentally destroyed while in the keeping of John Stuart Mill. Meets Southey and Wordsworth, and becomes friends 
with John Sterling. In the next five years his circle of London friends expands to include Leigh Hunt, Harriet Martineau, Erasmus Darwin, Monckton Milnes, John Forster, Dickens, Thackeray, Tennyson, FitzGerald, and Browning.

1836 Sartor Resartus first published in book form in Boston.

1837 Gives seven public lectures on German literature beginning in May. The French Revolution is published.

1838 Course of twelve lectures on European literature. Sartor Resartus is published in book form in London. With Emerson's help, Critical and Miscellaneous Essays is published in Boston.

1839 Six lectures on the revolutions of modern Europe. "On Chartism" published. Plays a formative role in the creation of the London Library.

1840 Delivers six lectures on heroes. Spends the summer in Scotland, henceforth an annual practice, and considers writing a biography of Cromwell.

1841 On Heroes, Hero-Worship, and the Heroic in History published.

1842 While visiting the Bury St. Edmunds area, he conceives the idea for Past and Present.

1843 Past and Present published.

1844 John Sterling dies.

1845 Oliver Cromwell's Letters and Speeches published.

1847 Emerson visits England and spends time with the Carlyles.

1848 Carlyle meets Sir Robert Peel, whom he admires and whose leading role in the repeal of the Corn Laws he has supported.

1849 Carlyle tours Ireland with his friend Gavan Duffy and finds English policies substantially responsible for the condition of Ireland. Writes his Reminiscences of My Irish Journey, published posthumously in 1882. Anger and despair about political and cultural conditions in Britain expressed in reviews and essays, including "Occasional Discourse on the Negro Question," published in Fraser's Magazine; contemplates a work on the negative effects of democracy, materialism, and sexual permissiveness. 
1850 Publishes Latter-Day Pamphlets, a series of eight satirical essays on the condition of modern Britain. Ruskin visits Carlyle for the first time and soon becomes a disciple. Friendships with a younger generation of intellectuals and writers, including William Allingham and John Tyndall.

1851 Life of John Sterling. In the fall, he visits Paris, accompanied by Robert and Elizabeth Browning. Begins to consider Frederick the Great as a subject for a biography.

1852 In the late summer, travels to Germany for the first time, visiting sites associated with Luther, Goethe, and Frederick the Great.

1856 Completes the writing of the first two volumes of Frederick the Great.

1857-58 Collected Works (the Uniform Edition) published in sixteen volumes.

1858 First two volumes of Frederick the Great published. In late summer, makes a second visit to Germany to complete a survey of sites associated with Frederick.

1863 Jane Carlyle's health deteriorates. Volume 3 of Frederick the Great is published.

1864 Volume 4 of Frederick the Great is published.

1865 Completes Frederick the Great; volumes 5 and 6 are published. In November he is elected Lord Rector of Edinburgh University, an honorary position.

1866 On April 2, Carlyle delivers his "Inaugural Address" in Edinburgh. On April 21, Jane Carlyle dies of a stroke. Carlyle writes a biographical and autobiographical memoir of Jane and another of Edward Irving, both later included in Reminiscences. In the fall joins the Governor Eyre committee whose purpose is to defend Eyre against the charge that his suppression of the Jamaican slave revolt (1865) was too harsh.

1867 Writes brief memoirs of Southey, Wordsworth, and William Hamilton. In August, he publishes a satiric attack on the Reform Bill of 1867, "Shooting Niagara: And After?" The essay also attacks environmental pollution. Ruskin and Carlyle become estranged. 
1868-69 Works sporadically at a selected edition of Jane's letters, then decides to postpone publication.

1869 A second edition of the Collected Works (the Library Edition, thirty volumes) begins publication. In March, he has an interview with Queen Victoria.

1870 Publishes a letter in the Times strongly supporting Germany in the Franco-Prussian War.

1871 Turns over to James Anthony Froude some personal papers and manuscripts, particularly Jane's letters, in effect appointing Froude his biographer and Jane's editor. In 1873 he gives Froude most of the remaining documents. His right hand becomes palsied, making it difficult for him to write.

1872 He dictates Early Kings of Norway (1875), but finds dictation an unsatisfactory way of writing.

1873 Carlyle's portrait is painted by Whistler.

1874-75 Enters the controversy about the authenticity of a portrait of John Knox and dictates an essay, "Portraits of John Knox" (1875).

1875 His eightieth birthday in December is the occasion for an international celebration, with gifts, honorary degrees, testimonial letters, and an engraved gold medallion. He declines Disracli's offer of a title.

1875-76 Publishes two letters in the Times opposing Disraeli's policy of support for the Turks against the Russians.

1879 Visits Scotland. With the death of his favorite younger brother John, he has outlived most of his family and personal and professional friends.

1881 On February 5, Carlyle dies at Cheyne Row. He is buried on February 10 next to his parents in the churchyard at Ecclefechan. 
This page intentionally left blank 